\title{
Effect of the Elevation of Old Dam Gap on Water Temperature Discharged for Fengman Rebuilt Project
}

\author{
Tiegang Zheng, Shuangke Sun, Haitao Liu, Han Jiang \& Guangning Li \\ Sate Key Laboratory of Simulation and Regulation of Water Cycle in River Basin, China Institute of Water \\ Resources and Hydropower Research, Beijing 10038, China
}

\begin{abstract}
A full three-dimensional flow-temperature coupled mathematics model was established combined with Fengman station. At the same time, a physical model test was carried out. Based on the research for different elevations with $235.0 \sim 244.0 \mathrm{~m}$ on water temperature discharged, it is pointed that the elevation of old dam gap has rare influence on the temperature in the winter; however, the influence becomes larger in the summer. The results also show that the elevation of old dam gap with $237.5 \sim 244.0 \mathrm{~m}$ all could improve the temperature requirements for Fengman Rebuilt Project.
\end{abstract}

KEYWORD: Old dam; water temperature; discharge; Fengman project; rebuilt

\section{INTRODUCTION}

Fengman Dam $\left(43^{\circ} 43^{\prime} \mathrm{N}, 126^{\circ} 41^{\prime} \mathrm{E}\right)$, built in 1937 , is one of the largest hydroelectric power facilities in China located on the Songhua River. The State Electricity Regulatory Commission defined Fengman Dam in 2007 as a "sick dam" because some structural problems that compromised safety (Z.X. Zhao et al, 2013). Given importance of Fengman Dam and seriousness of possible accidents it may cause, the National Development and Reform Commission approved a reconstruction program for the dam in 2010. The new dam, which is to be operational in 2012, is located $120 \mathrm{~m}$ downstream of old dam and is mainly used for power generation. It is also used for flood control, irrigation, urban water supply, and environmental protection.

With important implications of water temperature for biotic responses, it became clear that the thermal characteristics of reservoirs play a crucial role to manage downstream temperatures (J.D. Olden et al, 2010) (J.E. Thorpe, 2004). In reservoirs, the outlets might release water that is too warm or too cold for downstream ecosystems, depending on reservoir temperature at the intake. It is extremely detrimental to the health of fish in rivers, especially during their migration seasons (D. Caissie, 2006). From the power station operation before, the tailwater temperature withdrawn from Fengman Dam is only $10{ }^{\circ} \mathrm{C}$ $\sim 15^{\circ} \mathrm{C}$, which is too cold to delay their migration season. Different from other rebuilt projects, in order to reduce the impact on ecological environment in downstream as far as possible, only sections of the old dam were demolished. Considering the role of the front retaining wall played by old dam, there would be an increase in the temperature withdrawn in summer, what would improve habitat for the native fishes. However, because the temperature was inversion distribution in the reservoir, the temperature withdrawn will be less than before in winter. Along with the downstream, the water temperature decreased gradually, it will have negative effects on the domestic water, industrial water, and rime landscape. Therefore, the old dam played a crucial role in the temperature withdrawn, and the elevation of old dam gap is the key indicator. In present paper, combined with the temperature withdrawn in summer and winter, the elevation of old dam gap would be studied specially, the results would be offer scientific basis to Fengman reconstruction program.

\section{METHODS}

\subsection{Mathematical Modelling.}

The 3D model is based on the commercial code FLUENT 6.3. The implicit RANS solver employs a cell-centered finite-volume scheme and a hybrid unstructured mesh. The continuity equation is satisfied using the SIMPLE pressure-velocity algorithm. An additional scalar transport equation is solved to account for temperature effects through the Boussinesq assumption (M. Haque et al, 2007). The boundary conditions are programmed through user-defined functions. 


\subsection{Experimental methods and facilities.}

The experiments were performed in a 1:120 entire reservoir model at the hydraulics laboratory of IWHR. The entire model length was $8.0 \mathrm{~m}$. The sidewall height and model width were $1.5 \mathrm{~m}$ and $5.0 \mathrm{~m}$, respectively. The sidewalls and bed were made of concrete. The intake structures was made of plexi-glass. The physical model included three parts which were supplying zone, heating zone and testing zone. Water temperatures were real-time collected and dealt with using DJ800 data collecting system, which was designed by the hydraulics department of IWHR. The temperature measurement was accurate within $\pm 0.1{ }^{\circ} \mathrm{C}$, with a maximum range of $50.0{ }^{\circ} \mathrm{C}$. The water temperature withdrawal was measured at the downstream of tail pipe. The mathematical and experimental methods were discussed in detail in literature (T.G. Zheng et al, 2015), where the validated results were also shown.

\section{RESULTS AND ANALYSIS}

Figure 1 showed the water temperature withdrawn in January to March from Fengman hydropower. According to the operation data in winter, the water temperature was inverse distribution in reservoir, what was shown that the water temperature was nearly $0{ }^{\circ} \mathrm{C}$ at the surface, and it kept about $3.0{ }^{\circ} \mathrm{C}$ $\sim 4.0^{\circ} \mathrm{C}$ at the bottom. Because of the limiting condition for experiment, the prediction of water temperature withdrawn was carried out mainly from mathematical method. As shown in figure 1, the gap elevation increased from $235.0 \mathrm{~m}$ to $240.0 \mathrm{~m}$ in January, the water temperature withdrawn decreased 0.3 ${ }^{\circ} \mathrm{C}$, went on rising with $2.0 \mathrm{~m}$, the temperature decreased $0.1{ }^{\circ} \mathrm{C}$ again. However, when the gap elevation increased from $242.0 \mathrm{~m}$ to $244.0 \mathrm{~m}$, the temperature kept $2.5{ }^{\circ} \mathrm{C}$, in other words, there was no variation on temperature with the gap elevation changing. In February, the old dam gap elevation increased from $235.0 \mathrm{~m}$ to $240.0 \mathrm{~m}$, the water temperature withdrawn decreased $0.3{ }^{\circ} \mathrm{C}$, as same as in January, there was no variation on the water temperature when the gap elevation go on rising. Comparing with the temperature change in February, the water temperature withdrawn had some decrease in March, but the change rule was the same with that in February. Based on the numerical results on water temperature withdrawn in winter, it is shown that the water temperature decreased with the old dam gap elevation rising. In other words, the water temperature withdrawn will increase by means of decreasing the intake elevation.

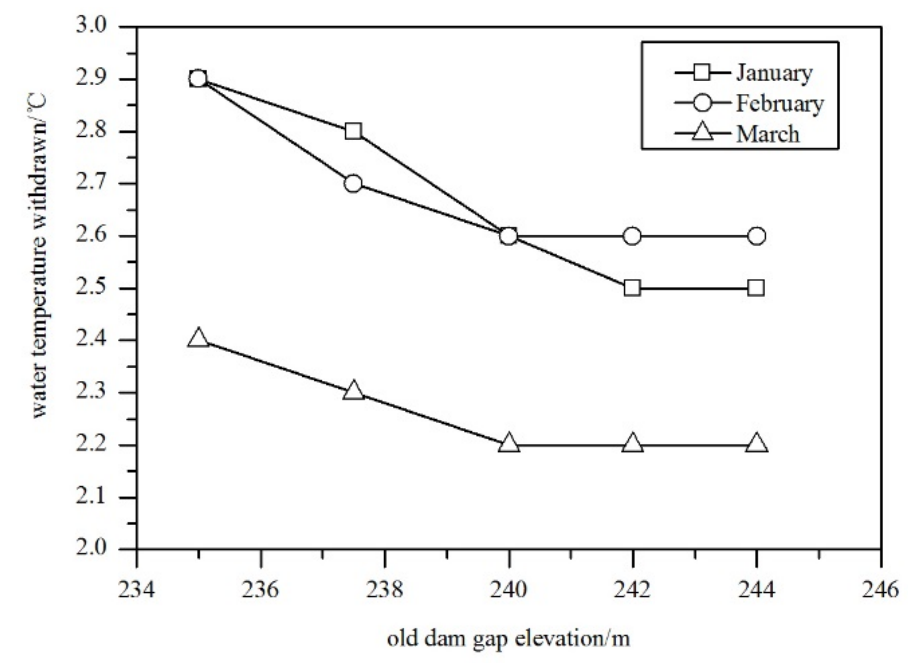

Figure 1 Water temperature withdrawn in January to March

The water temperature withdrawn in May to $\mathrm{Au}-$ gust from Fengman hydropower is shown in figure 2. Comparing with the reservoir temperature distribution in winter, the distribution took an overturn, what is shown that water temperature at the surface is much higher than that at the bottom. As shown in figure 5, in May, the water temperature withdrawn was $7.6{ }^{\circ} \mathrm{C}$ when the old dam gap elevation was $235.0 \mathrm{~m}$. With the elevation rose $2.5 \mathrm{~m}$ to $237.5 \mathrm{~m}$, the water temperature became $7.8{ }^{\circ} \mathrm{C}$, with a $0.2{ }^{\circ} \mathrm{C}$ increase. When the elevation rose to $240.0 \mathrm{~m}$, the increase of water temperature became $0.1{ }^{\circ} \mathrm{C}$. With the elevation rising, the water temperature increasing. However, when the gap elevation rose to $242.0 \mathrm{~m}$ or higher, the increase became no longer clear. In June, the water temperature withdrawn is about $14.5^{\circ} \mathrm{C}$ after reconstruction with $235.0 \mathrm{~m}$ gap elevation. If the elevation rose to $237.5 \mathrm{~m}$, the increase of water temperature withdrawn reached about $0.5^{\circ} \mathrm{C}$, which is much higher than that in May. However, with the elevation rising, the increase value decreased to $0.1^{\circ} \mathrm{C}$, which is the same with that in May. Except that, the gap elevation threshold for water temperature withdrawn increasing is $242.0 \mathrm{~m}$ too.

Comparing with June, the initial water temperature withdrawn increased to $20.0{ }^{\circ} \mathrm{C}$ in July, and the increase value was $0.8{ }^{\circ} \mathrm{C}$ when the gap elevation rose $2.5 \mathrm{~m}$. If the gap elevation went on rising $2.5 \mathrm{~m}$, the water temperature would increase $0.4{ }^{\circ} \mathrm{C}$, less than previous increase value. With the elevation rising, the water temperature increasing until the elevation reached to $242.0 \mathrm{~m}$. In August, the maximum value of water temperature was about $22.5^{\circ} \mathrm{C}$. However, the increase value was only $0.3{ }^{\circ} \mathrm{C}$ when the gap elevation rose to $237.5 \mathrm{~m}$, which was different from that in July. It was shown that rising the old gap elevation could improve the water temperature withdrawn clearly in summer for Fengman reconstruction program. However, the research results indicated that the increase value of water temperature was not in proportion to the old dam gap elevation. 
With the gap elevation rising, the increase value of water temperature decreasing; and when the elevation reached to some value, the water temperature would change no longer.
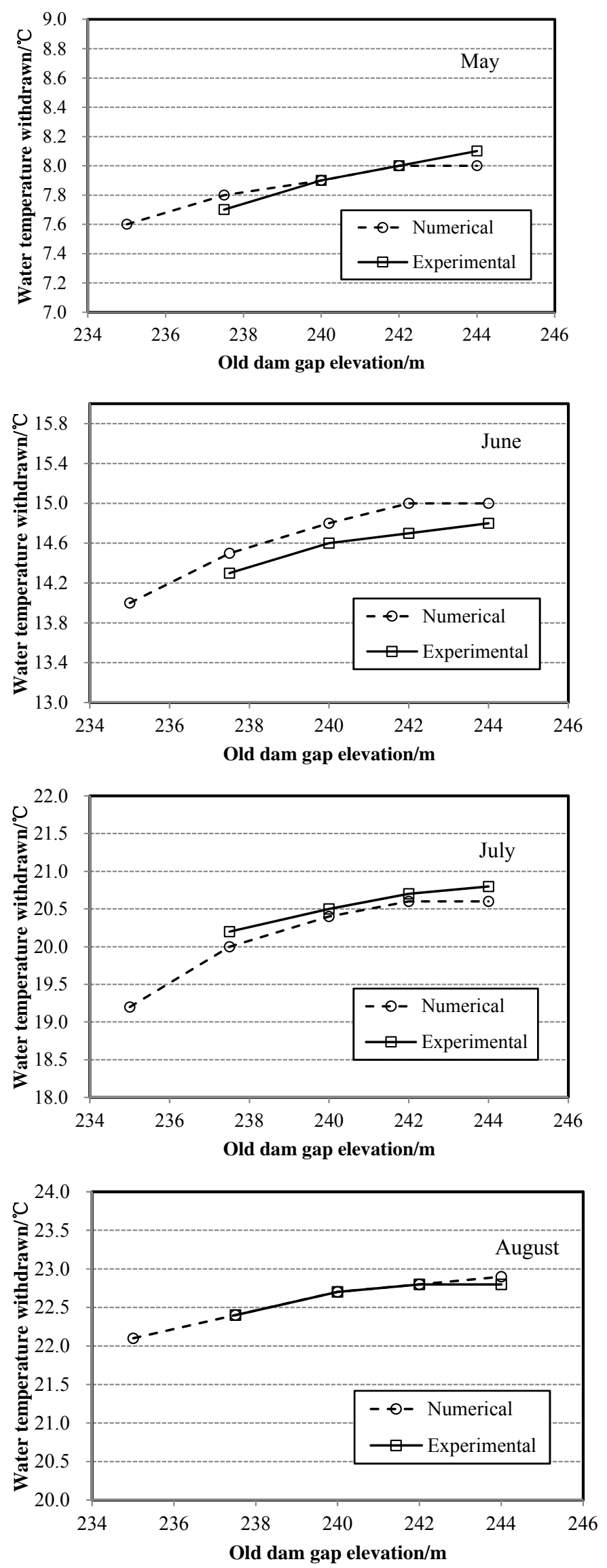

Comparing with winter operation period, the influence becomes much larger in summer. As shown in figure 1 and 2 , the gap elevation rose from $235.0 \mathrm{~m}$ to $237.5 \mathrm{~m}$, the maximum increase value was $0.8{ }^{\circ} \mathrm{C}$, happened in July. when the elevation rose from $237.5 \mathrm{~m}$ to $244.0 \mathrm{~m}$, the maximum increase values of water temperature of numerical and experimental were $0.6{ }^{\circ} \mathrm{C}$ and $0.7{ }^{\circ} \mathrm{C}$ respectively, which was also happened in July. Different from that in July, there was much less influence in May. It was because that the water depth was about $20 \mathrm{~m}$ above old dam gap, the effect intake range was about $0 \sim 30 \mathrm{~m}$; based on the meteorological data for Fengman, the gradient of water temperature in reservoir was about $0.20^{\circ} \mathrm{C} / \mathrm{m}$ in the range of $0 \sim 30 \mathrm{~m}$ in May, which was about $0.59{ }^{\circ} \mathrm{C} / \mathrm{m}$ in June, therefore, a higher water temperature withdrawn in June was shown. Comparing with that, the gradient of water temperature increased to $0.72{ }^{\circ} \mathrm{C} / \mathrm{m}$ in July. In spite of high water temperature in reservoir in August, the gradient in the range of $0 \sim 30 \mathrm{~m}$ was only $0.43{ }^{\circ} \mathrm{C} / \mathrm{m}$. Because of that, the maximum increase value of water temperature withdrawn was happened in July. From the above studies, it was concluded that the water temperature withdrawn was not only related to the elevation of old dam gap, but also the vertical gradient of water temperature in reservoir. The gradient was larger, the variation of water temperature withdrawn was larger.

In conclusion, according to the requirement of Fengman reconstruction program, it was aim to improve the detrimental to the health of fish in rivers, in other words, to increase the water temperature withdrawn. Based on the numerical and experimental results, with the old dam gap elevation rising, the water temperature increasing. It was analysis that when the old dam gap elevation rose from $235.0 \mathrm{~m}$ to $244.0 \mathrm{~m}$, the water temperature withdrawn only had a little decreased, $0.4{ }^{\circ} \mathrm{C}, 0.3{ }^{\circ} \mathrm{C}$, and $0.2{ }^{\circ} \mathrm{C}$ in January to March respectively. However, there were some increase in summer with about $0.5{ }^{\circ} \mathrm{C} \sim 0.8{ }^{\circ} \mathrm{C}$ when the gap elevation rose from $235.0 \mathrm{~m}$ to $237.5 \mathrm{~m}$. If went on rising the elevation to $240.0 \mathrm{~m}$, the increase value decreased to about $0.3{ }^{\circ} \mathrm{C}$. But when the elevation rose from $240.0 \mathrm{~m}$ to $244.0 \mathrm{~m}$, the increase value was only about $0.2{ }^{\circ} \mathrm{C}$ against $4 \mathrm{~m}$ increase for gap elevation. It is concluded from above results that when the old dam gap elevation is lower than $237.5 \mathrm{~m}$, the influence of gap elevation on water temperature withdrawn is clear. However, if the elevation is higher than $240.0 \mathrm{~m}$, the influence becomes little. Therefore, considering the effect on water temperature withdrawn in summer and winter, it is suggested that the old dam gap elevation should be about $237.5 \mathrm{~m}$ to $240.0 \mathrm{~m}$ for Fengman reconstruction project.

Figure 2 Water temperature withdrawn in May to August 


\section{CONCLUSION}

In order to investigate the influence of intake elevation on the water temperature, discuss its sensibility, a full three-dimensional flow-temperature coupled mathematics model was established combined with Fengman station. At the same time, a physical model test was carried out. Based on the results, it was pointed that the calculated results and experimental results were validated each other, which indicated that the methods in present paper were feasible, the results were accurate and reliable. It was concluded that the influence of old dam gap elevation on water temperature withdrawn was little in winter operation period, while it was clear in summer operation period. Considering the effect on water temperature withdrawn in summer and winter, it is suggested that the old dam gap elevation should be about $237.5 \mathrm{~m}$ to 240.0m for Fengman reconstruction project.

\section{ACKNOWLEDGEMENTS}

This work was supported by the National Natural Science Foundation of China (Grant No. 51309256, 51269028). The field data in the work are offered by Fengman Dam Reconstruction Engineering Construction Bureau.

\section{REFERENCES}

D. Caissie, The thermal regime of rivers: a review. Freshwater Biology, 51(2006):1389-1406.

J.D. Olden, R.J. Naiman, Incorporating thermal regimes into environmental flows assessments: modifying dam operations to restore freshwater ecosystem integrity. Freshwater Biology, 55(2010): 86-107.

J.E. Thorpe, Life history responses of fishes to culture. Journal of Fish Biology, 65(2004): 263-285.

M. Haque, G. Constantinescu, L. Weber, Validation of a 3D RANS model to predict flow and stratification effects related to fish passage at hydropower dams. Journal of Hydraulic Research. 45(2007), 787-796.

T.G. Zheng, S.K. Sun, H.T. Liu, et al. Sensibility analysis of intake elevation on water temperature discharged from a large thermal stratified reservoir. Journal of hydraulic engineering, 46(2015): 714-722.

Z.X. Zhao, L. Wei, L. Chang, The study of key technology on the environmental evaluation for Fengman reconstruction project. Water Resource and hydropower engineering, 44(2013): 57-59. 